matter before the proper authorities, and until my paper is published I must ask that the judgment of those concerned in this matter be deferred. I will only say here that Mr. Lamber has claimed a priority for Dr. Fleming which that gentleman himself would not have claimed, seeing that he was one of the editors of the Veterinarian in 1872, and that in the September number of that journal an essay is printed which was read by me at a meeting of the West of Scotland Veterinary Association, held in Glasgow in August of that year, on the subject of Tuberculosis, and in which the following remarks occur: "If the contagious character of tuberculosis is established, another (though perbaps a remote one) source of contamination is opened up before us-viz., from persons or animals eating raw or improperly cooked meat; or, more strongly, livers or other internal organs from animals that have suffered from this affection" (p. 682). "There are few animals the subject of tubercle whose carcases should be used for human food, no matter what the monetary loss may be" (p. 684).

I am, Sirs, yours obediently,

Thomas Walley.

Royal Veterinary College, Edinburgh, Feb. 28th, 1888.

\section{"TENOTOMY AND RAPID REDUCTION OF DEFORMITY."}

To the Editors of THE LANCET.

SIRs,-I wish to add to the opinion expressed in your issue of Feb. 25th by Mr. Noble Smith my own testimony as to the value of the "immediate method" of treating talipes. For two years I have been in the habit of placing the foot at once in the correct position, and in no instance have $I$ found reason to regret having done so. I gathered from Mr. Marsh's paper that he still adopted the custom of dividing the tendons in equino-varus from before backwards, as usually practised. My own experience is that in all infants it is wiser to divide the tendo Achillis first, and in the majority of the cases so treated there will be no need to interfere either with the plantar fascia or the tibialis. It is in cases treated in this manner that the manipulation as described by Mr. Marsh proves so serviceshle. I am, Sirs, yours obediently,

Nottingham, Feb 26th, 1888 Liwis W. MARshaLL, M.D.

\section{TRAUMATIC ANEURYSM FOLLOWING SUB- CUTANEOUS OPERATION. \\ To the Editors of THE LANCET.}

Sins,-The paper by Mr. Howard Marsh, in your issue of Feb. 18th, on Rapid Extension of the Foot after Tenotomy, and the case of Aneurysm of the Plantar Artery, seported in a recent number by Mr. Walsham, are of much interest when considered together, apart from that which each possesses independently.

On the general plan of treating deformities of the foot which Mr. Howard Marsh advocates 1 do not propose to offer any criticism, for, as he justly writes, there must be a good deal of latitude of opinion on such a question; but the method of applying extension directly upon the subcutaneous section of any tissue appears to me to favour the development of an aneurysm in the event of an artery being wounded, and to this point I venture to call attention. I note that the extension is advised to be carried on in three stages, and that the writer does not advocate immediate extension. By the latter term evidently is meant complete immediate extension, as opposed to the partial immediate extension which is recommended. I his latter method, from the report given, appears to have been followed in the case reported by Mr. Walaham. It is stated that the foot was placed in plasterof-Paris after section of the plantar fascia, and no mention is made of the casing being removed or reapplied during the time the child was in the hospital. To the employment of immediate extension I should attribute the derelopment of aneurysm in this case. In performing subcutaneous section of contracted tissues on the inner side of the sole of the foot, it is almost impossible to avoid dividing the internal plantar artery, and also, no doubt, in many cases the posterior tibial artery is wounded when tenotomy of the tendon of the tibialis posticus muscle is attempted. That traumatic aneurysm very seldom becomes developed under such cir- cumstances is somewhat remarkable, and is probably due to the general practice adopted of applying pressure to the divided parts, and of allowing the foot to remain in the position of distortion for a day or so before commencing to reduce the deformity. With this plan of treatment any divided tissues, other than those which are contractile, are kept in apposition under pressure, thus favourably placed for the severed ends of an artery to become closed. When extension - whether complete or partial-is made, a space is supplied within which a traumatic aneurysm may very readily be formed. For this reason I would suggest that in all cases after subcutaneous operation pressure should be applied, and the divided tissues be kept as nearly as possible in their former positions, until the fourth or fifth day. With this precaution extension may be subsequently employed, after what manner the surgeon may select, without any risk of an aneurysm becoming developed.

February, 1888. I am, Sirs, yours truly, F. R. FISHER.

BIRMINGHAM.

(From our oun Correspondent.)

\section{BIRMINGHAM ATHLETIC CLUB,}

LORD CHARLES BERESFORD presided at the twenty-second annual display held by this club at the Town Hall on the 21st inst. At the close of the performances he expressed his belief that it was necessary at the present time to encourage in this way every kind of manly sport, because so many people were driven from the country into the towns, where it was impossible to get fresh air and exercise sufficient to keep them healthy or even cheerful by other means. He was of opinion that, the service rendered by the army and navy, where ability, chivalry, and pluck were exhibited, was mainly brought about by lives of exercise. It conduced also to sobriety and self-denial, and in this respect tended to solve one of the greatest problems of the day. An enthusiastic reception and a cordial vote of thanks showed how much these remarks were appreciated by a large and admiring audience.

THE HEALTI OF THE BOROUGH.

At a meeting of the Town Council held on February 21st the Health Committee offered a most satisfactory report. The death-rate, it was pointed out, had declined most notably, and now Birmingham stands at the head of the towns with which it is compared. Thus the average annual death-rate for the preceding ten years was a little over 24 per 1000 , while in the ten years ending 1887 it was a little over 20 per 1000 . Bearing in mind the increase of the population, and the density in some areas of the town, this must be regarded as an encouraging indication of the results attained by the sanitary improvements which have been constantly going on. There is ground for still greater advance, and the direction in which this might profitably be expected is in the saving of infunt life. So many causes combine to uphold this constant sacrifice that it is only by the greatest viglance and determined care that the prevention will come. Warnings are insufficient, protests are of no avail, teaching is futlle; while helpless infants are overlain, crammed with unsuitable food, or lett without fireguards in the midst of danger, to say nothing of the many ways in which they are exposed to diseases by indifference to natural laws and common sense.

HOW INFECTION MAY BE EPREAD.

The inspector of nuisances for the Solihull Sanitary Authority lately reported to the board an instance of an outbreak of scarlet fever which he had traced to its source. He obtained a list of absentees from the school, and, on investigating the cases, found in one house a girl desquamating from scarlet fever, while several children belonging to neighbours were playing about the house. A baskt of washing had just bten returned to a house where there was a large family. In another house he found three children with scarlet fever, with one in a state of desquamation attending the school. From here also a basket of washing had been sent to a house with a family of children. In all, ten children were sent to the infectious hospital; one was treated at home. Wisely, the medical officer ordered the schools to be closed. Such ignorance as shown by the parents of the affected children is plainly culpable, and calls for 